\title{
Sosialisasi English for Young Learners (EYL) bagi Guru Sekolah Dasar di Gugus II Kecamatan Ciamis
}

\author{
Lystiana Nurhayat Hakim ${ }^{1 *}$, Tri Agustini Solihati² \\ ${ }^{12}$ Program Studi Pendidikan Bahasa Inggris, Universitas Perjuangan Tasikmalaya \\ Email: lystiananurhayat@unper.ac.id ${ }^{1}$,triagustini@unper.ac.id ${ }^{2}$ \\ *Corresponding author: lystiananurhayat@unper.ac.id ${ }^{1}$
}

\begin{abstract}
ABSTRAK
Perubahan Kurikulum membuat mata pelajaran Bahasa Inggris di Sekolah Dasar berubah dari muatan lokal menjadi program ektrakurikuler. Berdasarkan data pra-observasi, di Kecamatan Ciamis pengajaran Bahasa Inggris mengalami beberapa kendala seperti kualifikasi guru yang bukan Sarjana Pendidikan Bahasa Inggris, pengunaan teknik serta metode mengajar Bahasa Inggris yang monoton dan menjenuhkan, kurangnya sumber ajar, serta tidak adanya pelatihan dan pembinaan pengajaran Bahasa Inggris bagi pembelajar anak. Melihat berbagai permasalahan tersebut maka penulis melakukan pengabdian kepada masyarakat dengan memberikan pelatihan pengajaran Bahasa Inggris dan Forum Group Discussion (FGD) bagi guru-guru Sekolah Dasar di Kecamatan Ciamis. Hasil pengabdian ini menunjukan bahwa guru memiliki motivasi yang baik dalam meningkatkan kompetensi mereka dalam pengajaran Bahasa Inggris, pemahaman mereka terhadap karakteristik pembelajar anak juga meningkat, serta adanya peningkatan kemampuan guru untuk menciptakan pengajaran yang bermakna dan menyenangkan.

Kata kunci: Pengajaran, Bahasa Inggris, Sekolah Dasar
\end{abstract}

\section{Socialization of English for Young Learners (EYL) for Elementary School Teachers in Cluster II Ciamis Kecamatan District}

\begin{abstract}
The change of curriculum makes English subjects in Elementary School move from local content to the extracurricular program. Based on pre-observation data, there are some obstacles face by the teacher in teaching English to young learners in Ciamis. Those are the unqualified English teachers, the monotonous of teaching techniques and methods, the lack of using teaching sources, and the unavailable of EYL workshops. Therefore, to solve those problems the author conducted a community service in the form of the EYL workshop and FGD. The community service makes the teachers' motivation to improve their competency in English language teaching increase. Besides, their understanding of the characteristics of children and their ability to create meaningful and interesting teaching also increase.
\end{abstract}

Keywords: Teaching, English, Elemntary School 


\section{PENDAHULUAN}

Pemerintah

Indonesia

mengakui bahwa bahasa Inggris sangat penting dalam sistem pendidikan yang telah berlangsung selama beberapa tahun terakhir ini. Bahasa Inggris memiliki pengaruh yang sangat kuat dalam dunia modern dan menjadi salah satu alat komunkasi yang sangat penting dalam hubungan Internasional. Wijaya (2015, p.122) mengatakan bahwa Bahasa Inggris di Indonesia secara umum diajarkan sebagai bahasa asing yaitu bahasa yang yang tidak digunakan sebagai alat komunikasi dan biasanya diajarkan sebagai salah satu mata pelajaran di sekolah dengan tujuan berkomunikasi dasar serta menguasai empat skill berbahasa (menyimak, membaca, menulis, berbicara).

Dalam hal ini pemerintah Indonesia kemudian memberi kebijakan untuk mengenalkan pelajaran bahasa Inggris di Sekolahsekolah Dasar. Kebijakan pemerintah tentang pelajaran bahasa Inggris di sekolah dasar secara resmi dinyatakan dalam Kebijakan Depdikbud RI No. 0487/4/1992, Bab VIII, menyatakan bahwa sekolah dasar dapat menambah matapelajaran dalam kurikulumnya, asalkan pelajaran itu tidak bertentangan dengan tujuan pendidikan nasional. Kemudian, kebijakan ini disusul oleh SK Menteri Pendidikan dan Kebudayaan No. 060/U/1993 tanggal 25 Februari 1993 tentang dimungkinkannya program bahasa
Inggris sebagai mata pelajaran muatan lokal di SD, dan dapat dimulai pada kelas 4 SD.

Namun pada kurikulum 2013 pembelajaran bahasa Inggris menjadi kegiatan ekstrakurikuler. Kedudukan pembelajaran bahasa Inggris pada setiap perubahan kurikulum menegaskan bahwa pembelajaran tersebut dianggap penting untuk dipelajari sejak dini (Azizah \& Surya, 2017, p.11). Dengan demikian maka diperlukan adanya penataan pembelajaran bahasa Inggris di SD. Penataan paling penting adalah kesiapan guru, oleh karena itulah diperlukan adanya kegiatan peningkatan kemampuan guru dalam mengajarkan bahasa Inggris (Yamin, 2017, p.82).

Dalam perjalanannya kebijakan nasional ini ditanggapi secara positif oleh masyarakat, yaitu sekolahsekolah dasar yang merasa memerlukan dan mampu untuk menyelenggarakan pengajaran bahasa Inggris. Dalam perjalanan pengembangannya, bahasa Inggris yang semula sebagai matapelajaran muatan lokal pilihan menjadi matapelajaran muatan lokal wajib di beberapa daerah. Kurikulum matapelajaran muatan lokal ini tidak disusun oleh Pusat Kurikulum Depdiknas tetapi dikembangkan di tingkat provinsi. Oleh karena itu, kurikulum muatan lokal di Jawa Barat akan berbeda dengan di daerah lainnya baik mengenai tujuannya maupun materinya (Suyanto, 2000). Berbeda dengan wilyah lainnya, di 
Lystiana Nurhayat Hakim, Tri Agustini Solihati/Aksiologiya: Jurnal Pengabdian Kepada Masyarakat. Vol. 5 No. 4 , November $2021 \mathrm{Hal} 450-458$

Kecamatan Ciamis pelajaran Bahasa Inggris menjadi muatan lokal wajib, oleh karena itu pelajaran Bahasa Inggris diajarkan mulai dari kelas satu hingga kelas enam.

Dalam konteks pembelajaran bahasa asing tidak seperti halnya mempelajari Bahasa Indonesia atau bahasa daerah dimana siswa dengan mudah dapat mengakses pada penggunaan bahasa dalam lingkungan sosial dimana mereka belajar, pengajaran Bahasa Inggris sebagai bahasa asing di Indonesia khususnya di Kecamatan Ciamis menghadapi banyak masalah serius.

Masalah yang pertama yaitu kurangnya akses pada penggunaan Bahasa Inggris dalam kehidupan nyata sehari-hari siswa di masyarakat. Dengan demikian siswa mengalami kesulitan untuk menyikapi pentingnya belajar Bahasa Inggris sebagai sesuatu yang berguna untuk kehidupan dimasa depan. Masalah yang kedua yaitu berhubungan dengan kata-kata dalam Bahasa Inggris dimana penulisannya berbeda dengan penguacapannya. Hal ini membuat sulit siswa untuk belajar Bahasa Inggris. Siswa akan merasa bingung ketika dia menemukan kata yang tertulis dalam bahasa Inggris. Siswa tidak akan dapat langsung mengucapkannya atau membacanya dengan benar sebagaimana pengucapannya dalam Bahasa Inggris.

Masalah selanjutnya adalah masalah kompetensi guru pengajar bahasa Inggris di SD Gugus II
Kecamatan Ciamis. Berdasarkan data yang diperoleh penulis, di beberapa SD yang ada di wilayah Gugus II Kecamatan Ciamis pengajar bahasa Inggris untuk SD ini adalah guru kelas yang diberi tugas untuk mengajarkan bahasa Inggris. Kebanyakan dari Guru kelas tersebut tidak mempunyai latar belakang pendidikan bahasa Inggris. Mereka hanya mempunyai pengalaman belajar bahasa Inggris ketika mereka sekolah di SPG atau SMA. Hal ini menyulitkan mereka dalam mengajarkan bahasa Inggris, karena mereka tidak mengetahui prinsipprinsip dasar pengajaran bahasa Inggris, terutama pengajaran bahasa Inggris untuk anak-anak. Dengan tidak tersedianya guru bahasa Inggris di SD yang kompeten dibidangnya, strategi belajarmengajar yang benar dan sesuai dengan kebutuhan pembelajaran siswa juga tidak bisa dikembangkan.

Permasalahan keempat adalah masalah ketersediaan bahan ajar atau buku ajar untuk pengajaran bahasa Inggris di SD. Karena pengajaran bahasa Inggris di Sekolah Dasar masih belum merupakan kegiatan kurikuler nasional, maka buku ajarpun tidak tersedia banyak. Hal ini menyebabkan guru menggunakan bahan ajar yang kesesuaian dan kemanfaatannya tidak bisa dipastikan, karena bahannya ajarnya hanya didasarkan pada pengetahuan, kemampuan, dan minat guru itu sendiri. Tetapi beberapa guru mengalami masalah karena kurang 
tersedianya buku pelajaran bagi mereka terutama di daerah yang jauh dari kota serta tidak semua siswa mempunyai buku pelajaran sehingga mereka harus berbagi dengan siswa lain.

Data yang diperoleh penulis menunjukkan bahwa kebanyakan guru bahasa Inggris di Gugus II Kecamatan Ciamis memakai buku pelajaran sebagai penuntun mereka dalam memberikan materi pelajaran bahasa Inggris, selain itu ditemukan bahwa ketersediaan buku pelajaran hanya terdapat di sekolah negeri atau swasta yang kualitasnya sangat bagus. Masalah tersebut juga ditambah dengan guru tidak mempunyai pedoman buku mana yang layak serta memenuhi standar untuk dipergunakan sebagai materi pembelajaran di kelas. Walaupun Radjab \& Syarif (2009, p.44) mengatakan bahwa guru harus selalu mengembangkan pengetahuan dan keterampilan mengenai strategi belajar-mengajar Bahasa Inggris di SD dengan membaca jurnal, namun penulis berpendapat bahwa hal ini tidak akan berhasil jika guru tidak mengimplementasikan hasil bacanya dan jika tidak ada pendampinga dari para pakar.

Kurang tersedianya buku pelajaran di sekolah serta metode mengajar yang menjenuhkan dapat menghambat atau menurunkan motivasi siswa karena pembelajaran bahasa asing akan sangat berguna apabila bahan pengajaran berkaitan dengan hal-hal kegiatan sehari-hari, atau menggunakan media nyata sehingga meningkatkan rasa ingin tahu siswa serta motivasi belajarnya.

Permasalahan kelima terdapat beberapa guru yang tidak paham akan perbedaan antara pengajaran bahasa Inggris sebagai bahasa asing untuk pembelajar anak-anak dan dewasa yang diantaranya ialah: (1) sebagai seorang pembelajar, anakanak lebih antusias dan bersemangat. (2) Mereka ingin menyenangkan gurunya dibandingkan teman dalam kelompoknya. (3) Mereka akan melakukan aktivitas yang diberikan guru walaupun mereka kurang mengerti mengapa dan bagaimana.

(4) Mereka lebih mudah untuk kehilangan minat belajar dan susah untuk menjaga dirinya untuk tetap termotivasi untuk belajar ketika dia menemukan kesulitan dalam belajar. (5) Mereka tidak mempunyai akses yang sama sebagaimana pembelajar dewasa terhadap meta-language yang digunakan guru untuk menjelaskan tentang tata bahasa atau wacana. (6) Mereka tidak malu-malu dalam belajar bahasa asing sehingga membantu mereka untuk memperoleh bahasa baru (Cameron, 2001). Dengan mengetahui karakteristik dari pembelajar anak-anak diharapkan guru dapat memikirkan tentang bahasa dan menciptakan cara yang tepat untuk mengajarkan bahasa Inggris untuk anak-anak di kelas.

Semua permasalahan tersebut menyebabkan mengajar Bahasa Inggris pada tingkat young learners di Indonesia tidak semudah yang 
Lystiana Nurhayat Hakim, Tri Agustini Solihati/Aksiologiya: Jurnal Pengabdian Kepada Masyarakat. Vol. 5 No. 4, November $2021 \mathrm{Hal} 450-458$

dibayangkan (Hakim, 2018, p. 4), dia menuturkan bhawa hal ini dikarenakan beberapa faktor seperti bahasa Inggris merupakan bahasa asing yang hanya dipelajari saja di sekolah dan tidak digunakan pada kehidupan sehari-hari, kurangnya pemahaman akan manfaat dan fungsi bahasa Inggris, adanya perbedaan cara membaca kata dengan tulisannya, adanya miskonsepsi mengenai bagaimana anak-anak belajar bahasa Inggris, dan tidak semua pengajar bahasa Inggris kompeten dalam mengajar, bahkan tidak sedikit pengajar yang bukan lulusan pendidikan bahasa Inggris mengajarkan bahasa Inggris pada siswanya.

Dengan memperhatikan permasalahan diatas, maka peletakan dasar yang kuat dalam dasar-dasar pengembangan kemampuan belajar bahasa Inggris di tingkat pendidikan dasar akan memungkinkan siswa mencapai tingkat kemampuan belajar bahasa Inggris yang baik dan efisien di tingkat pendidikan selanjutnya. Walaupun demikian persoalan prioritas yang ada pada guru-guru SD di Gugus II Kecamatan Ciamis ialah kurangnya pengadaan pelatihan pengajaran Bahasa Inggris bagi siswa SD oleh pemerintah maupun pihak lainnya. Oleh karena itu, dengan adanya kegiatan pelatihan dan lokakarya diharapkan mampu memberikan pengetahuan serta motivasi bagi guru-guru pengajar bahasa Inggris untuk meningkatkan kompetensi dalam mengajar bahasa
Inggris sehingga dapat meningkatkan mutu pengajaran bahasa Inggris dan kualitas kompetesi bahasa Inggris siswa yang diajarinya.

Tujuan

kegiatan

pengabdian ini ialah memberikan pengetahuan kepada guru SD tentang prinsip-prinsip pengajaran bahasa Inggris, memberikan pengetahuan kepada guru SD tentang metode dan teknik pengajaran Bahasa Inggris untuk siswanya, memberikan pengetahuan kepada guru SD tentang memilih dan menggunakan buku teks atau LKS dan media ajar lainnya yang lebih menarik untuk pengajaran Bahasa Inggris.

\section{METODE PENELITIAN}

Metode kegiatan Pengabdian ini dilakukan dengan metode participatory action research dalam bentuk ceramah, diskusi dan praktek. Ada beberapa tahapan pengabdian yang dilalui mulai dari perijinan kepada dinas terkait hingga pelaksanaan pengabdian yang dibagi menjadi 3 tahap pelatihan.

Pada pelatihan pertama tim pengabdian melakukan metode Forum Group Discussion (FGD) yaitu berupa pemaparan singkat tentang pemahaman serta pendalaman materi mengenai lima pilar mengajar Bahasa Inggris di Indonesia kemudian dilanjutkan dengan diskusi mengenai permasalahan yang dihadapi guruguru tersebut selama mengajar Bahasa Inggris. yang kemudian akan diberikan pemecahan masalahnya. Selanjutnya tim pengabdian 
melakukan pemaparan mengenai beberapa media ajar yang dapat mereka gunakan dalam mengajar bahasa Inggris bagi anak-anak, kelebihan dan kekurangannya, serta fungsi dan peranannya dalam kegiatan belajar mengajar Bahasa Ingggris.

Kemudian tim pengabdian juga memberikan pemaparan mengenai beberapa contoh multimedia yang dapat dipakai pada kegiatan belajar mengajar seperti YouTube, English for Kids, BBC English for Children, $C S M$, dan sebagainnya. Menrut Hakim (2019, p. 17) menyebutkan bahwa YouTube merupakan sumber belajar Bahasa Inggris yang bagus dan dapat meningkatkan motivasi belajar dan pemerolehan kosa kata siswa.

Pada kegiatan ini juga guruguru melakukan simulasi dan praktek dalam mengakses website tersebut, bagaimana cara mendownload, memilih materi yang tepat dari website, dan bagaimana menggunakannya pada kegiatan belajar mengajar Bahasa Inggris di Sekolah Dasar.

Pada pelatihan kedua tim pengabdian melakukan demonstrasi dan praktek oleh mengenai karakteristik buku yang baik dan tepat untuk anak-anak serta bagaimana cara memilih, menggunakan, dan mengevaluasi buku teks yang sesuai dengan kebutuhan siswa. Pada kegiatan ini guru-guru melakukan simulasi dengan bimbingan tim pengabdian, mereka akan membawa beberapa buku teks serta LKS yang tersedia di masing-masing sekolah pada kegiatan pelatihan, lalu buku teks serta LKS tersebut dianalisis dan dievaluasi menggunakan rubrik yang telah disiapkan oleh tim pengabdian.

Pada pelatihan kedua juga tim pengabdian melakukan demonstrasi dan praktek mengenai cara memilih cerita yang baik untuk anak-anak berdasarkan tingkatan atau level anak serta teknik mengajar menggunakan cerita. Cerita merupakan metode mengajar bahasa Inggris yang baik bagi anak karena cerita dapat meningkatkan motivasi anak, meningkatkan penemuan makna, kefasihan dalam linguistik, menjadi peduli pada sesama, menjadi stimulasi dalam berbicara juga menulis, menghbungkan fantasi serta imaginasi kedalam dunia nyata, serta mengembankan strategi belajar anak (Brester, Ellis and Girard 2003; Wright 1995).

Selanjutnya tim pengabdi memberikan beberapa contoh lagu dan permainan yang dapat dipakai dalam kegiatan belajar mengajar Bahasa Inggris. Pada kegiatan ini selain melakukan pemaparan dengan metode ceramah, tim pengabdi dengan dosen model melakukan demosntrasi pengajaran Bahasa Inggris untuk anaka-anak Sekolah Dasar dengan menggunakan lagu dan permaianan.

Sama dengan kegiatan sebelumnya, guru-guru dibagi menjadi beberapa kelompok lalu berdiskusi mengenai lagu dan 
permaianan yang akan dipilih untuk mengajar, kemudian guru-guru tersebut menampilkan simulasi pengajaran Bahasa Inggris menggunakan lagu dan permainan. Pada waktu yang bersamaan tim pengabdian mengevaluasi kegiatan simulasi yang telah ditampilkan oleh guru-guru tersebut.

Setelah semua rangkaian kegiatan pelatihan ini selesai, semua guru diberikan tugas untuk merekam kegiatan belajar mengajar dikelas masing-masing. Video tersebut kemudian dikumpulkan di Ketua Gugus II Kecamatan Ciamis yang selanjutnya dievaluasi oleh tim pengabdi. Kegiatan ini bertujuan untuk mengevaluasi kegiatan pengabdian sehingga tim pengabdi akan mengetahui sejauh mana tingkat keberhasilan kegiatan pelatihan ini.

\section{HASIL DAN PEMBAHASAN}

Kegiatan pengabdian ini disambut baik oleh semua pihak baik dari para steakholder maupun peserta pelatihan. Program ini sangat membantu para peserta dalam pengembangan pengajaran Bahasa Inggris bagi anak-anak agar dapat memberikan pengajaran yang kreatif, menyenangkan, bermakna, dan inovatif.

Motivasi peserta sangat baik, mereka datang tepat waktu, aktif dalam kegiatan, serta tidak segansegan untuk memberikan komen bahkan pertanyaan kepada pelaksana. Keberhasilan pelatihan ini terlihat pada saat peserta memahmai lima pilar mengajar bahasa Inggris di Indonesia seperti: 1) siapa anak-anak, 2) bagaimana anak-anak tersebut belajar, 3) bagaimana mereka belajar bahasa, 4) bagaimana anak-anak Indonesia belajar Bahasa Inggris sebagia bahasa asing, serta 5) bagaiman memfasilitasi mereka dalam belajar Bahasa Inggirs sebagai bahasa asing (Musthafa, 2008).

Peserta pun memahami karaketeristik pembelajar anak menurut Pinter (2006, p.2) dan Harmer (2007) seperti memiliki keterbatasan dalam menulis dan membaca, lebih mementingkan diri sendiri dibandingkan yang lain, memiliki keterbatasan pengetahuan akan dunia dan sekitarnya, memiliki dan menikmati hal-hal yang berhubungan dengan fantasi, imaginasi dan gerak, belajar secara tidak langsung dari sekitarnya, dari apa yang mereka lihat, dengar, dan sentuh, mudah kehilangan konsentrasi, perhatian belajar, dan jenuh setelah 10 menit, membutuhkan perhatian sebagai individu dari guru, serta senang bermain dan bergerak.

Selain itu kegiatan workshop berhasil mebuat peserta memberikan simulasi pengajaran yang kreatif dan inovatif sesuai dengan materi yang telah diberikan sebelumnya. Akan tetapi beberapa keluhan muncul pada saat mereka menggunakan bahasa Inggris, hal ini ternayat diakibatkan tidak semua guru SD di Kecamatan Ciamis adalah lulusan S1 Pendidikan Bahasa Inggris. Mereka menyadari 
akan kesalahan pada pronunciation dan gramma- nya.

Ekspresi bahagia dan puas pun terlihat pada wajah peserta hal ini juga sesuai dengan hasil kuesioner yg menunjukan bahwa 95\% dari mereka merasa puas akan pelatihan ini, serta $86 \%$ peserta menyatakan bahwa pengetahuan pengajaran bahasa Inggris anak-anak mereka meningkat. Oleh karena itu kepuasan mereka terhadap kegiatan ini membuat peserta dan panitia di Tingkat Gugus II Kecamatan Ciamis menginginkan kegiatan pelatihan ini diadakan lagi secara berkesinambungan, bahkan ingin adanya pendampingan bagi mereka. Besar harapan mereka untuk dapat mengikuti kegiatan ini lagi dilain kesempatan dengan materimateri terbaru lainnya.

\section{SIMPULAN}

Berdasarkan hasil pelatihan ini penulis memeperoleh kesimpulan bahwa sebagian guru bahasa Inggris SD di Kecamatan Ciamis tidak mempunyai pengetahuan mengenai pengajaran bahasa Inggris bagi young learners. Selain itu, para guru bahasa Inggris disana juga tidak pernah mengimplementasikan pengajaran yg kreatif dan inovatif. Hal ini dikarenakan mereka tidak memiliki pengetahuan serta pengalaman dalam mengimplementasikannya, buku serta artikel yang mereka baca pun kurang relevan sehingga banyak dari mereka yang kurang memahami bagaimana cara mengimplementasikannya, ditambah dengan dengan latar belakang pendidikan mereka yang bukan S1 Pendidikan Bahasa Inggris menjadi alas an mereka untuk melafalkan kata dengan pronounciation yang kurang tepat.

\section{DAFTAR PUSTAKA}

Azizah, D. M., Surya, A. (2017). Implementasi Pembelajaran Bahasa Inggris SD Berbasis Budaya Di Yogyakarta. Jurnal Riset Pedagogik. 1(2), 14-20.

Brewster, J. and Ellis, G. (2003). The Primary English Teacher's Guide. Essex: Penguin English.

Cameron, Lynne. (2001). Teaching Language to Young Learners. Cambridge: Cambridge University Press.

Hakim, L., N. (2018). Mengajar Bahasa Inggris Untuk AnakAnak Lebih Bermakna Dan Menyenangkan. Ciamis ; Galuh Nurani.

Hakim, L., N. (2019). The Implementation Of Youtube In Teaching Vocabulary For Young Learners. JOURNAL OF ADVANCED ENGLISH STUDIES, Vol. 2, No.1, February 2019, Page 13-18.

Harmer, J. (2007). The Practice of English Language Teaching (4th Ed). United Kingdom: Pearson Education Limited.

Musthafa, B. 2008. Teaching English to Young Learners: Principles and Techniques, Bandung, PPsUPI Press.

Pinter, Anamaria. (2006). Teaching 
Lystiana Nurhayat Hakim, Tri Agustini Solihati/Aksiologiya: Jurnal Pengabdian Kepada Masyarakat. Vol. 5 No. 4, November 2021 Hal $450-458$

Young Language Learners. New York: Oxford University Press.

Radjab, D., \& Syarif, H. (2009). Pelaksanaan Pembelajaran Bahasa Inggris Di Sekolah Dasar Kota Padang. Lingua Didaktika Volume 3 No. 1 Tahun 3, Desember 2009

Suyanto, Kasihani K. E. 2000. Senang Belajar Bahasa Inggris di Sekolah Dasar: Penelitian 10 Provinsi di Indonesia. Malang : Lemlit Universitas Malang.

Wijaya, I. K. (2015). Pembelajaran Bahasa Inggris Di Sekolah Dasar. BAHTERA: Jurnal Pendidikan Bahasa Dan Sastra, 14(2), 120. https://doi.org/10.21009/bahter a. 142.02

Yamin, M. (2017). Metode Pembelajaran Bahasa Inggris Di Tingkat Dasar. JURNAL PESONA DASAR Vol. 1 No. 5, April 2017, hal. 82 - 97. 